\title{
Eight years of monitoring aquatic Oligochaeta from the Baía and Ivinhema Rivers
}

\author{
Behrend, RDL. ${ }^{\mathrm{a} *}$, Fernandes, SEP. ${ }^{\mathrm{a}}$, Fujita, S. ${ }^{\mathrm{a}}$ and Takeda, AM. ${ }^{\mathrm{b}}$

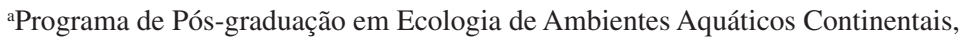 \\ Universidade Estadual de Maringá - UEM, \\ Av. Colombo, 5790, CEP 87020-900, Maringá, PR, Brazil \\ 'Departamento de Biologia, Núcleo de Pesquisas em Limnologia Ictiologia e Aqüicultura - Nupélia, \\ Universidade Estadual de Maringá - UEM, \\ Av. Colombo, 5790, CEP 87020-900, Maringá, PR, Brazil \\ *e-mail: romulobehrend@yahoo.com.br
}

Received November 10, 2008 - Accepted March 4, 2009 - Distributed June 30, 2009

(With 8 figures)

\begin{abstract}
The aim of this study was to analyze the factors that influence spatial and temporal variations of the Oligochaeta assemblage in the Baía and Ivinhema Rivers, located in the Upper Paraná River floodplain (Mato Grosso do Sul State, Brazil). Samples of Oligochaeta were collected between February 2000 and November 2007. A total of 27 Oligochaeta species were identified. A Principal Component Analysis (PCA) of the physical and chemical variables was used to summarize the total variation in the data and to identify major environmental gradients. Detrended Correspondence Analysis (DCA) was conducted to verify possible spatial and temporal gradients in the Oligochaeta species distribution. The highest Oligochaeta species densities and richness values were recorded during limnophases. The intensity and amplitude of the potamophase influenced the density, richness and composition of Oligochaeta since many species were transported by high water current velocities and/or died due to the low oxygen levels that are characteristic of this phase. L. hoffmeisteri, P. descolei and A. pigueti were recorded in the potamophase and in the limnophase and we concluded that they are adapted to different conditions of rivers (lotic and lentic) due to the presence of these species during the entire study period in both rivers. Nevertheless, these species were dominant in the potamophase periods of these rivers as they have body adaptations to survive in these conditions.
\end{abstract}

Keywords: Oligochaeta species, Baía and Ivinhema Rivers, flood pulse intensity and amplitude.

\section{Oito anos de monitoramento de Oligochaeta aquáticas nos Rios Baía e Ivinhema}

\section{Resumo}

O objetivo do estudo foi analisar os fatores que influenciam as variações espaciais e temporais da assembléia de Oligochaeta nos Rios Baía e Ivinhema, localizados na planície de inundação do Alto Rio Paraná. (Estado do Mato Grosso do Sul, Brasil). As amostras de Oligochaeta foram coletadas de fevereiro de 2000 a novembro de 2007. Um total de 27 espécies foi identificado. Análise de Componentes Principais (PCA) das variáveis físicas e químicas foi usada para sumarizar a variação total nos dados e identificar os principais gradientes ambientais. Para verificar possíveis gradientes espaciais e temporais na distribuição das espécies de Oligochaeta foi realizada uma Análise de Correspondência Dendrítica com remoção do efeito de arco (DCA). As maiores densidades e riqueza de espécies de Oligochaeta foram registradas nos períodos de águas baixas. A intensidade e amplitude da potamofase influenciaram a riqueza, densidade e composição de espécies, uma vez que muitas das espécies foram carreadas pela alta velocidade de corrente de água e/ou mortas devido aos baixos níveis de oxigênio que foram característicos dessa fase. L. hoffmeisteri, P. descolei and A. pigueti foram registradas nos períodos de potamofase e limnofase e nós concluímos que são adaptadas a diferentes condições de rios (lótico e lêntico) devido a preseça dessas espécies durante todo período estudado em ambos os rios. Contudo, essas espécies foram dominantes nos períodos de potamofase desses rios uma vez que elas apresentam adaptações corporais para sobreviver nessas condições.

Palavras-chave: espécies de Oligochaeta, Rios Baía e Ivinhema, intensidade e amplitude do pulso de inundação. 


\section{Introduction}

Floodplains are areas that are periodically flooded by the lateral overflow of rivers or lakes, and/or direct precipitation or groundwater. Fluctuations in physical and chemical variables of the water in these environments causes the biota to respond through morphological, physiological, anatomical, phenological, and/or ethological adaptations and to produce characteristic community structures (Junk et al., 1989). The degree of connection between the river and its floodplain depends on the water level. The river and its wetlands must be considered one unit because its water, sediment and organic budgets are interrelated (Junk, 1980; Junk et al., 1989).

Physical and chemical variations in rivers and their floodplains are usually associated with fluctuations in the water levels, and this characteristic leads to the formation of the flood-pulse concept or the pulse concept (Junk et al., 1989; Neiff 1990a) encompassing both the dry and the flood phases. These phases are important for the biocenosis and regulation of environments (Neiff, 1990b; Neiff et al., 1994).

The flood pulse is the major force in floodplains, and it regulates community structure and ecosystem function (Junk et al., 1989; Neiff 2005; Casco et al., 2005; Agostinho et al., 2008; Takeda and Fujita, 2004). The main attributes of the pulse can be spatial, such as amplitude, intensity and tension, or temporal, such as frequency, recurrence and seasonality, which is also related to the historical behavior of the spatial attributes (Neiff, 1990a, Neiff et al., 1994, Neiff and Malvárez, 2004).
The hydrosedimentological dynamics of large rivers create a high degree of habitat heterogeneity, and this is reflected in the spatial and temporal structures of the benthic community (Marchese and Ezcurra de Drago, 1992). Oligochaeta is an abundant group of benthic organisms (Ezcurra de Drago et al., 2004), and this group is registered in almost all freshwater environments and is abundant in several environments in the Upper Paraná River (Montanholi-Martins and Takeda, 1998; Takeda, 1999; Takeda et al., 1997; Stevaux and Takeda, 2002; Takeda and Fujita, 2004).

This study investigated the hypothesis that the flood pulse modifies the Oligochaeta community structure, and aimed to analyze factors that influence spatial and temporal variations in Oligochaeta assemblages.

\section{Materials and Methods}

\subsection{Study area and sampling stations}

The alluvial floodplain of the Upper Paraná River has an asymmetric geometry, with a floodplain on only the right bank of the fluvial channel, and a grade that is about $6 \mathrm{~km}$ wide and 3 to $5 \mathrm{~m}$ above the mean river level. This floodplain is drained by an anastomosed system of channels (Stevaux and Santos, 1998) that is formed by the Baía River, the Curutuba and Araçatuba channels (which represent old Paraná River channels) and the lower section of the Ivinhema River (Santos, 2005) (Figure 1).

The Ivinhema River (22 ${ }^{\circ} 47^{\prime}$ 59.64" $\mathrm{S}$ and $53^{\circ} 32$ ' 21.3 ' W) is an important right-bank tributary of

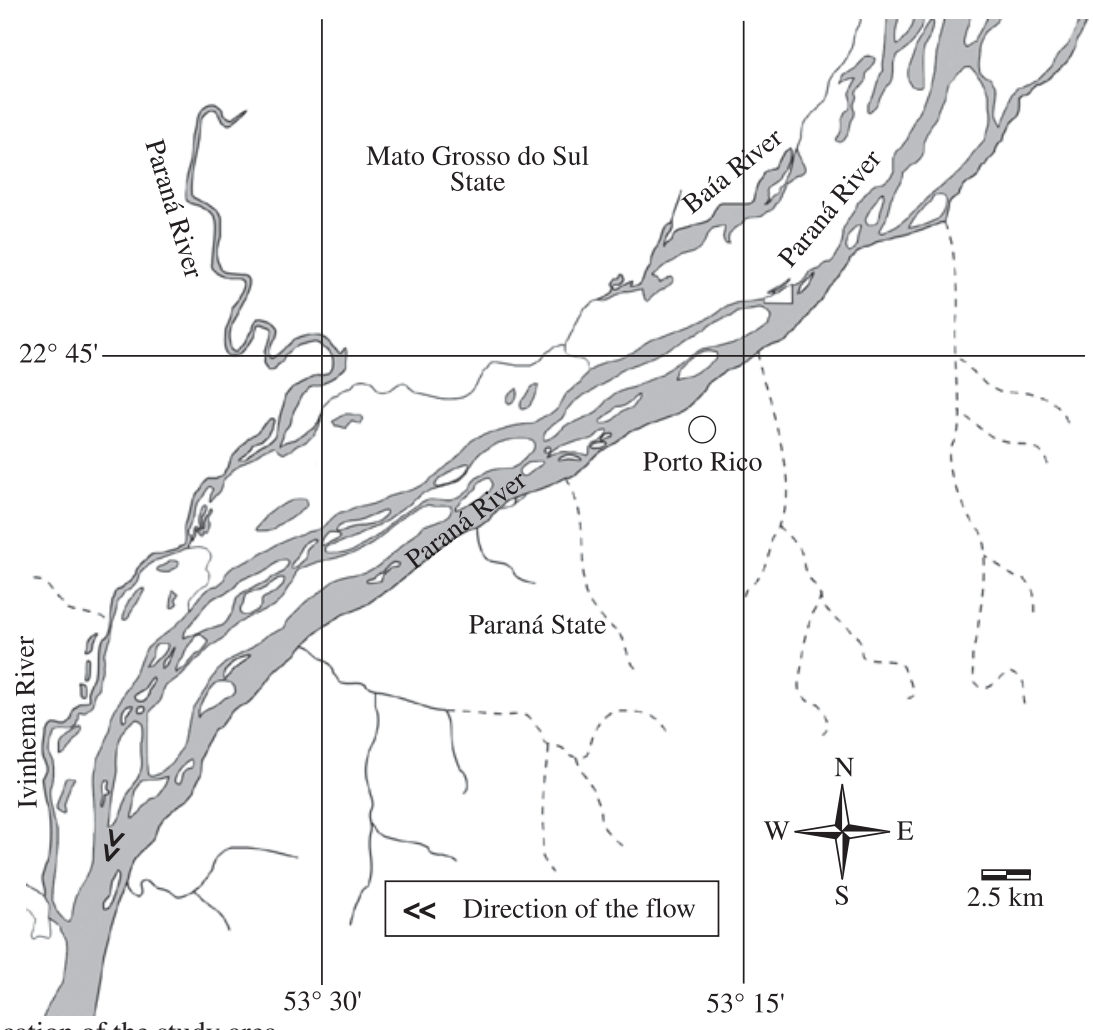

Figure 1. Location of the study area. 
the Upper Paraná River, and it cuts a series of terraces, geomorphic surfaces, floodplains and associated features (Fortes et al., 2005).

The Baía River (22॰43’23.16” S and 53 17’25.5”W) is situated on the right bank of the Paraná River in the Mato Grosso do Sul State. It is a sinuous channel and is considered to be a lentic environment because of its reduced water speed.

Water flow into this floodplain can occur due to floods of the Paraná and Ivinhema Rivers (Souza Filho, 2009). During the potamophase period of the Paraná River, water flow into the floodplain initially begins with groundwater elevation and continues until there is a connection with the lentic bodies, which occurs at a flood level of $3.5 \mathrm{~m}$. The increase in river level elevation up to $4.6 \mathrm{~m}$ is provided by water entrance through the low banks of the fluvial channels and lakes, and initiates flooding in the "Curutuba/Ivinhema" area. The intermediate sections of the river overflow into the floodplain at a level of $6.0 \mathrm{~m}$ and cover the highest parts of the floodplain at a level of 7.0 m (Rocha, 2002; Meurer, 2004; Corradini, 2006; Souza Filho, 2009).

In floods of the Ivinhema River, water flow through the groundwater has not yet been determined, but the beginning of the floodplain occurs from the $2.5 \mathrm{~m}$ level of the Fluviometric Station of Ivinhema (Souza Filho, 2009).

\subsection{Data collection}

Samples for the study of Oligochaeta assemblages were collected quarterly from February 2000 to November 2007, except for November 2001, and March and September 2003. In 2001 and 2003, only three and two annual collections, respectively, were conducted. In the Ivinhema and Baía Rivers, samples were collected at three sites along a transect: two margins and one in the central part of the river. In each site, three samples were taken with a modified Petersen grab $\left(0.0345 \mathrm{~m}^{2}\right)$ for biological analysis.

The sediment was washed in $2.0,1.0$ and $0.2 \mathrm{~mm}$ sequential sieves. The sediment retained on the last sieve was fixed in $70 \%$ alcohol, and was sorted using a stereomicroscope. Oligochaeta species were identified using an optical microscope and the key created by Brinkhurst and Jamieson (1971), Brinkhurst and Marchese (1991) and Righi (1984).

The hydrological data were provided by the Agência Nacional de Águas (ANA) and Itaipu Binacional, and the following variables were provided by Limnology Laboratory of Nupelia: conductivity (Digimed DM-3P), $\mathrm{pH}$ (Digimed DM-2P), temperature and dissolved oxygen (YSI-550A). The periods under the influence of La Niña and El Niño were defined according to McPhaden et al. (2006).

\subsection{Data analysis}

The water level data were analyzed from 2000 to 2007 using the attributes of f FITRAS (Neiff, 1990a) obtained with the PULSO program (Neiff and Neiff, 2003)
(Table 1). The Fluvial Connectivity Quotient (FCQ) (Neiff and Neiff, 2003) refers to the intensity of the connectivity. The $4.6 \mathrm{~m}$ level required for the Paraná River to influence the Baía and Ivinhema Rivers and the $2.5 \mathrm{~m}$ level in the Fluviometric Station of Ivinhema were considered to be boundary levels between high water (potamophase - Neiff, 1990) and low water (limnophase Neiff, 1990) phases (Souza Filho, 2009).

To assess the structure of the Oligochaeta assemblages, density (ind. $\mathrm{m}^{-2}$ ) and species richness $(\mathrm{S})$ were calculated. A non-parametric two-factor analysis of variance (Kruskal-Wallis test) (Zar, 1984) was used to test the difference between Oligochaeta species and sampling periods.

Principal Component Analysis (PCA) of the physical and chemical variables was used to summarize the total variation in the data and to identify major environmental gradients (Gauch, 1986). The abiotic data used were temperature, dissolved oxygen, conductivity, $\mathrm{pH}$, organic matter (Table 2) and the hydrometric levels of the Ivinhema and Paraná Rivers. These data were analyzed using PC-ORD 4.0 (McCune and Mefford, 1999).

The mean density of Oligochaeta species was analyzed using Detrended Correspondence Analysis (DCA). The biotic data were $\log (x+1)$-transformed to minimize the effects of discrepant values. Rare species (less than two observations) were removed to improve data interpretation. Eight of the 27 species in the DCA met this criterion.

\section{Results}

\subsection{Abiotic factors}

Potamophase periods were generally observed during warmer months (December to March). However, in some years a second flood event was recorded between May and September in the Ivinhema River (Figures 2 and 3). The hydrosedimentological cycle of the Ivinhema River exhibited a bimodal pattern in most of the studied years, except for 2001 and 2004.

In the Paraná River floods did not occur in 2000, 2001 (La Niña years, in which low precipitation values were obtained) and 2004, and the hydrometric level in these years was always below $4.6 \mathrm{~m}$. During this period, the Paraná River recorded the highest intensity (IL) and amplitude (AL) of the limnophase and the lowest values of FCQ (Table 1). On the other hand, higher hydrometric levels were recorded from January to March in 2002, 2003, 2005, 2006 and 2007, which combined with the occurrence of El Niño, when high precipitation values were also obtained.

A higher amplitude (AP) and intensity of the potamophase (IP) was recorded in the Ivinhema River in 2001 and in the Paraná River in 2007 and 2005, respectively (Table 1). Regarding the number of complete pulses (CP) and the FCQ, the greatest values were recorded in the Ivinhema River.

In the Principal Component Analysis (PCA), the first two axes explained $57 \%$ (axis $1=37 \%$ and axis $2=20 \%$ ) of the total data variability. 
Table 1. Attributes of $f$ FITRAS measured in the Paraná River (Porto São José) and in the Ivinhema River (Porto Sumeca) between 2000 and 2007. AP, AL: Total Amplitude of Potamophase and Limnophase, IP, IL: Intensity of Potamophase and Limnophase. FCQ: Fluvial Connectivity Quotient. CP: number of Complete Pulses.

\begin{tabular}{cccllll}
\hline Attributes & AL & IP & IL & AL & FCQ & CP \\
\hline Years & & & & & \\
Ivinhema & & & & & & \\
28 & 338 & 3.83 & 0.84 & 0.08 & 1 \\
2001 & 98 & 267 & 4.79 & 1.06 & 0.36 & 7 \\
2002 & 18 & 347 & 3.18 & 0.8 & 0.05 & 1 \\
2003 & 13 & 352 & 2.81 & 0.86 & 0.036 & 2 \\
2004 & 50 & 316 & 3.44 & 0.82 & 0.15 & 4 \\
2005 & 52 & 313 & 4.55 & 0.83 & 0.16 & 2 \\
2006 & 41 & 324 & 2.91 & 0.94 & 0.12 & 4 \\
2007 & 69 & 296 & 4.29 & 0.71 & 0.23 & 3 \\
Paraná & & & & & \\
2000 & 3 & 363 & 5.07 & 2.04 & 0.008 & 1 \\
2001 & 0 & 365 & 4.14 & 1.17 & 0 & 0 \\
2002 & 10 & 355 & 5.3 & 1.89 & 0.028 & 2 \\
2003 & 9 & 356 & 5.02 & 1.96 & 0.025 & 2 \\
2004 & 0 & 366 & 4.34 & 1.95 & 0 & 0 \\
2005 & 33 & 332 & 6.76 & 1.98 & 0.09 & 5 \\
2006 & 13 & 352 & 5.16 & 2.2 & 0.03 & \\
2007 & 55 & 310 & 6.45 & 2.16 & 0.17 & 3 \\
\hline
\end{tabular}

The attributes of FITRAS are defined as follows:

The amplitude of the phase is the duration of droughts and floods of a determined magnitude in a determined place on the floodplain. The intensity of the phase is the intensity caused by a drought or an inundation.

The fluvial Connectivity Quotient $=$ FD/ID

where FD is the number of flooding days (potamophase)

and ID is the number of isolated days (limnophase)

The complete pulses (potamophase + limnophase).

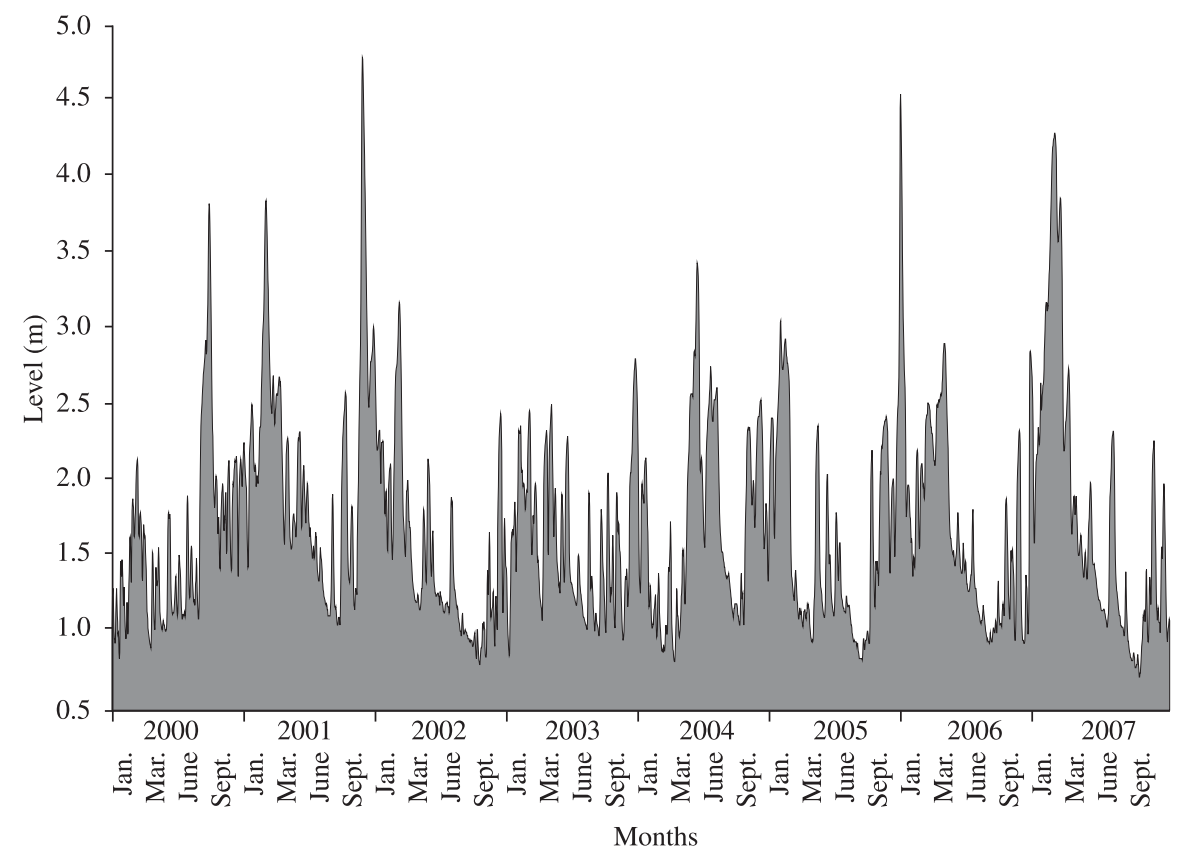

Figure 2. Hydrometric level of the Ivinhema River, obtained in the Fluviometric Station of Ivinhema from 2000 to 2007. 


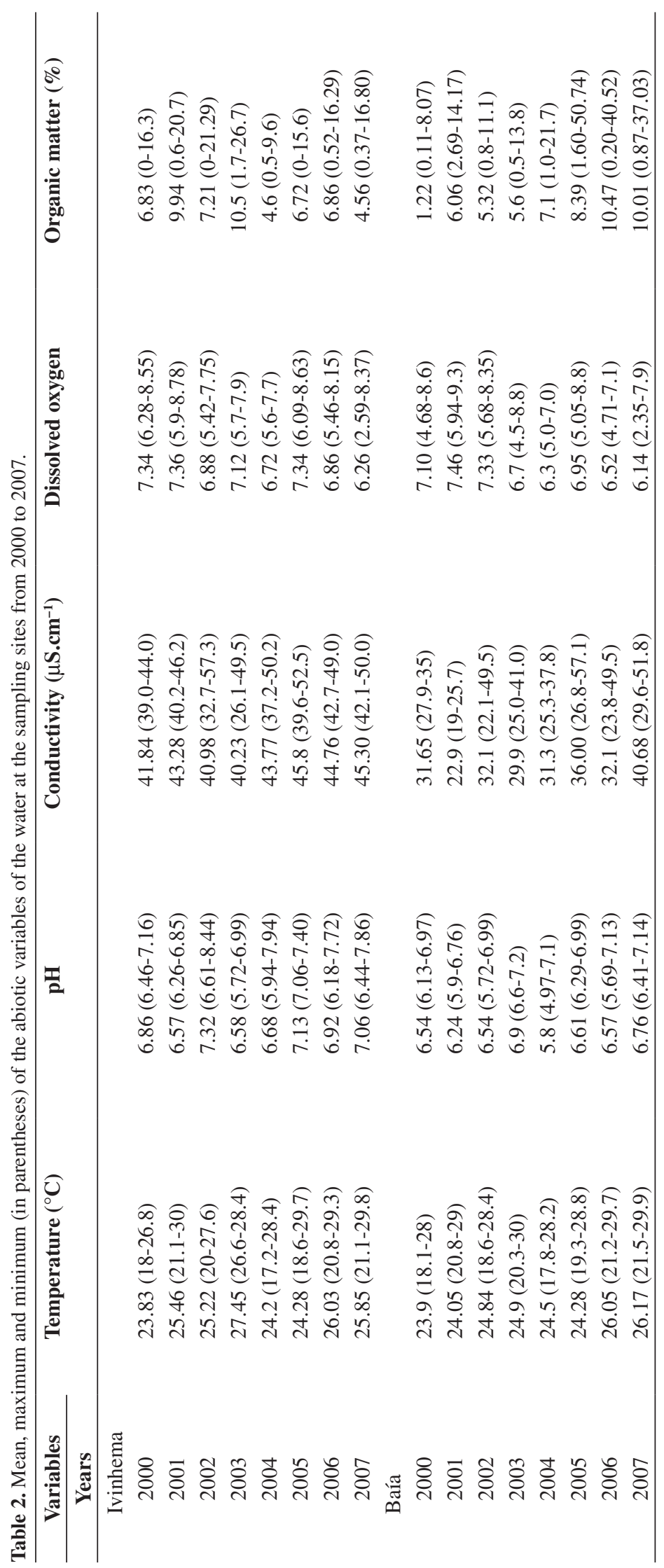


In the axis 1, dissolved oxygen contributed the highest positive correlation, while temperature and levels of the Paraná and Ivinhema Rivers had the highest negative correlations. On axis 2, the variables that correlated positively with the variability were $\mathrm{pH}$ and conductivity, and the level of the Ivinhema River had the largest negative correlation (Figure 4).
Axis 1 showed differences between the environments due to dissolved oxygen and temperature values that were different during the potamophase and limnophase periods. The limnophase periods in the Baía and Ivinhema Rivers occurred during the colder months (May to September), whereas the potamophase periods coincided with high temperatures. On axis 2, the two

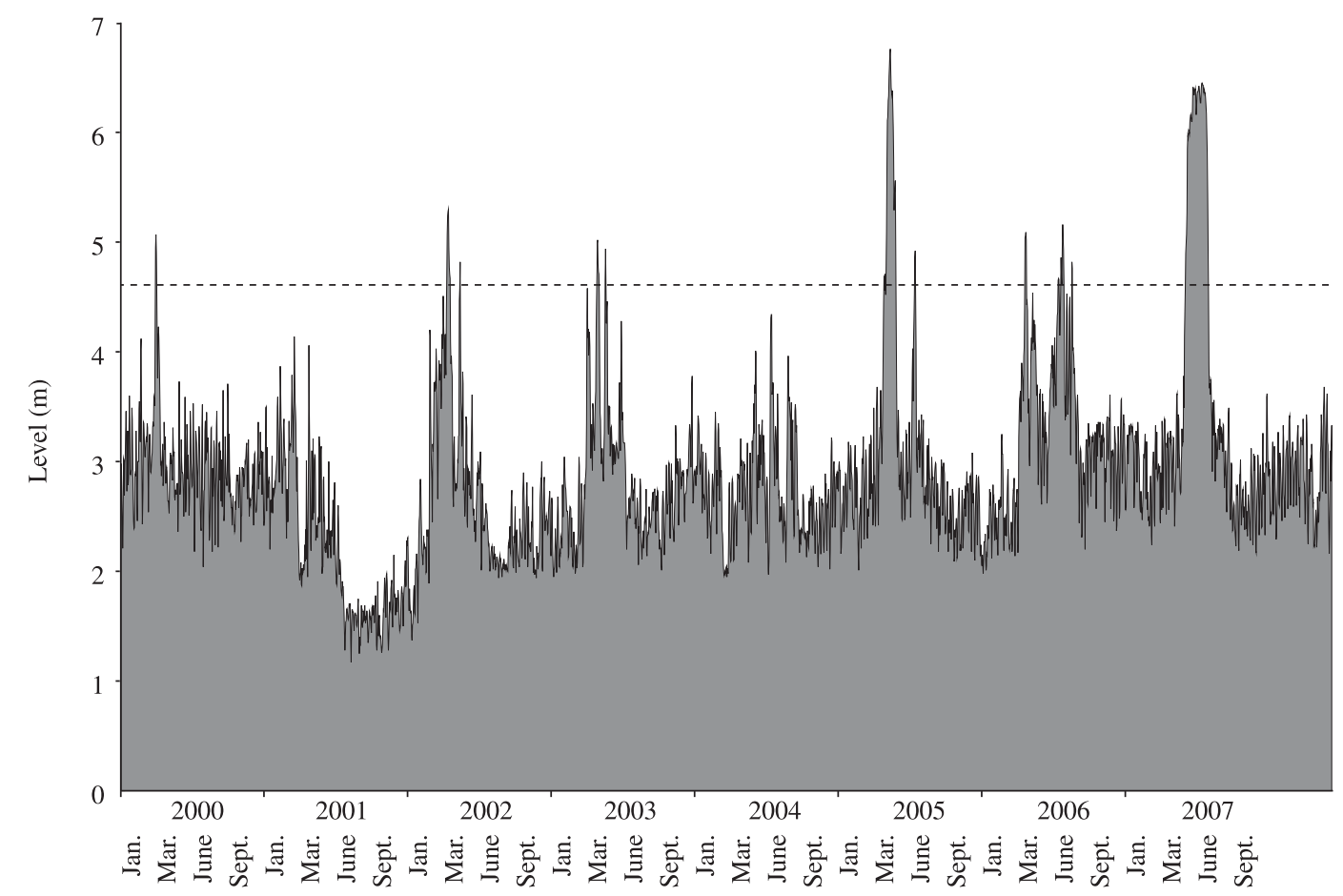

Months

Figure 3. Hydrometric level of the Paraná River, obtained in the fluviometric station of Porto São José from 2000 to 2007.


Figure 4. a) Ordination of the scores for each sampling station, in relation to axes 1 and 2 of the principal component analysis (PCA); and b) Autovector of the variables used in the principal component analysis. 
environments differed based on high values of $\mathrm{pH}$ and conductivity recorded in the Ivinhema River and in the lower Baía River (Figure 4).

\subsection{Aquatic oligochaeta composition}

In this study, 7250 Oligochaeta individuals from seven families were recorded: Alluroididae, Enchytraeidae, Haplotaxidae, Narapidae, Opistocystidae, Naididae and Tubificidae. The Enchytraeidae individuals were not identified at the specific level and considered as species for the analysis. Naididae was responsible for $56 \%$ of the collected species in the Baía River and $52 \%$ in the Ivinhema River (Table 3).
Higher mean densities of Oligochaeta were recorded in February and May 2000 in the Ivinhema River and in May and August of the same year in the Baía River (Figure 5). A Kruskal-Wallis test showed that there was a significant difference only between the Oligochaeta density and the collection periods $(\mathrm{H}=50.95 ; \mathrm{p}<0.05)$.

A higher percentage of Narapa bonettoi was observed in the Ivinhema River from 2000 to 2002. After 2005, Limnodrilus hoffmeisteri, Paranadrilus descolei and Aulodrilus pigueti dominated this river (Figure 6a). The Baía River had different dominant species during the years of the study (Figure 6b).

Table 3. Presence and absence of aquatic Oligochaete species during the flood (Potamophase) and drought (Limnophase) periods of the Ivinhema and Baía Rivers.

\begin{tabular}{|c|c|c|c|c|}
\hline Station & Baía & Baía & Ivinhema & Ivinhema \\
\hline Periods & Drought & Flood & Drought & Flood \\
\hline ENCHYTRAEIDAE & + & - & - & - \\
\hline \multicolumn{5}{|l|}{ HAPLOTAXIDAE } \\
\hline Haplotaxis aedeochaeta (Brinkhurst and Marchese, 1987) & - & - & + & - \\
\hline \multicolumn{5}{|l|}{ OPISTOCYSTIDAE } \\
\hline Opistocysta funiculus (Cordero, 1948) & - & - & + & - \\
\hline \multicolumn{5}{|l|}{ NARAPIDAE } \\
\hline Narapa bonettoi (Righi and Varela, 1983) & + & - & + & + \\
\hline \multicolumn{5}{|l|}{ NAIDIDAE } \\
\hline Pristina americana (Cernosvitov, 1937) & + & - & + & + \\
\hline P. macrochaeta (Cernosvitov, 1939) & + & - & + & - \\
\hline P. leidyi (Smith, 1896) & - & - & + & - \\
\hline P. aequiseta (Bourne, 1891) & + & - & + & - \\
\hline P. proboscidea (Beddard, 1896) & + & - & + & - \\
\hline P. osborni (Walton, 1906) & + & - & - & - \\
\hline Bratislavia unidentata (Harman, 1973) & - & - & + & - \\
\hline Dero sp. & + & - & + & - \\
\hline Dero (Dero) plumosa (Naidu, 1962) & + & - & - & - \\
\hline D. (D.) righii (Varela, 1990) & - & - & + & - \\
\hline D. (D.) digitata (Muller, 1773) & + & - & + & - \\
\hline D. (D.) sawayai (Marcus, 1943) & + & - & + & - \\
\hline D. (D.) multibranchiata (Steiren, 1892) & + & - & - & - \\
\hline Dero (Aulophorus) borellii (Michaelsen, 1900) & + & - & - & - \\
\hline D. (A.) furcatus (Muller, 1773) & + & - & + & - \\
\hline Nais communis (Piguet, 1906) & + & - & + & - \\
\hline Slavina evelinae (Marcus, 1942) & + & - & + & + \\
\hline Stephensoniana trivandrana (Aiyer, 1926) & + & - & + & + \\
\hline \multicolumn{5}{|l|}{ TUBIFICIDAE } \\
\hline Limnodrilus hoffmeisteri (Claparede, 1862) & + & + & + & + \\
\hline Paranadrilus descolei (Gavrilov, 1955) & + & + & + & + \\
\hline Aulodrilus pigueti (Kowalewski, 1914) & + & + & + & + \\
\hline Bothrioneurum americanum (Beddard, 1894) & + & - & + & - \\
\hline \multicolumn{5}{|l|}{ ALLUROIDIDAE } \\
\hline Brinkhurstia americana (Brinkhurst, 1964) & + & - & + & - \\
\hline
\end{tabular}




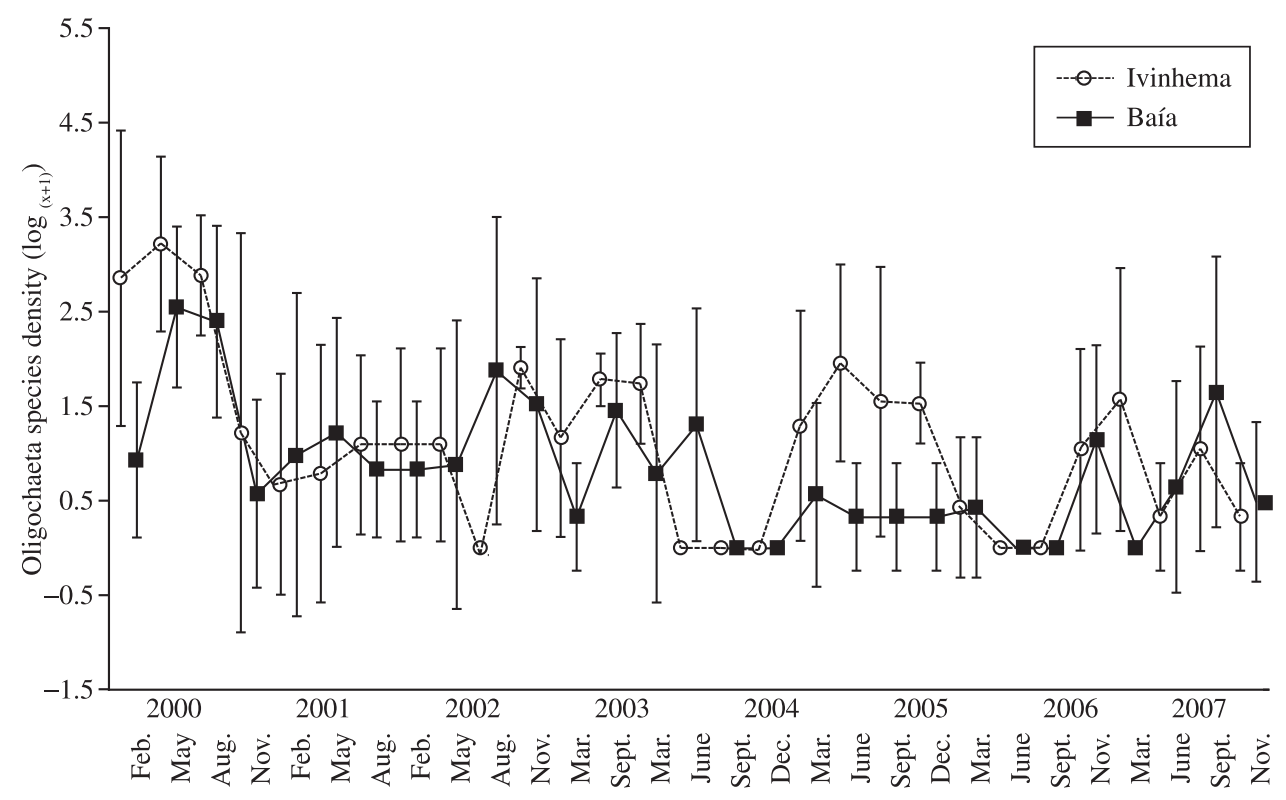

Months

Figure 5. Oligochaete species density $\left(\log _{(x+1)}\right)$ in the Ivinhema and Baía Rivers over an eight year period.

The highest value of species richness was observed in the Ivinhema River in June 2005 while the highest value in the Baía River occurred in August 2000 (Figure 7). A Kruskal-Wallis test showed a significant difference only between species richness and the collection periods $(\mathrm{H}=47.27$; $\mathrm{p}<0.05)$.

To verify possible spatial and temporal gradients in the Oligochaeta species distribution, a Detrended Correspondence Analysis (DCA) (eigenvalues on axis $1=0.99$ and on axis $2=0.53$ ) was conducted, and indicated three separate groups. Group 1 was formed mainly in the limnophase periods of the Baía River, where a greater number of Oligochaete species was observed. Group 2 was observed during the limnophase and potamophase periods of the Ivinhema River and the potamophase period of Baía River, and included P. descolei, L. hoffmeisteri and A. pigueti. Group 3 comprised the limnophase periods of the Ivinhema River from 2000 to 2002 when higher densities of Haplotaxis aedeochaeta and N. bonettoi were observed (Figure 8).

\section{Discussion}

Early ecologists recognized that environmental conditions were temporally dynamic (McIntosh, 1985), and the temporal study contributed significantly to its generalizations and/or predictions. Observations distributed across several days or months may differ from those that span years or decades because longer studies have a greater probability of observing or helping to explain slow, rare, subtle or complex changes in natural environments (Likens, 1989; Elliott, 1990; Risser, 1991; Cody and Smallwood, 1996, Jackson and Füreder, 2006).
Long-term studies of lotic macroinvertebrates communities are rare (Jackson and Füreder, 2006), particularly over broad spatial scales, but the perspectives of such studies are valuable for identifying interactions between spatial and temporal variability (Collier, 2008). Few long-term studies have been conducted on the Oligochaeta community in fluvial systems (Nijboer et al., 2004). The absence of those studies does not allow us to understand or to assess environments with great variability, such as those found in areas that are sometimes flooded.

The pulse acts as a disturbance factor in fluvial macrosystems, removing organisms and allowing new spaces and resources to become available (Hildrew and Giller, 1994). The degree of disturbance is a function of the frequency, intensity, tension, regularity, amplitude and seasonality of the "pulses" ( $f$ FITRAS) (Neiff, 2001), of the connectivity (Ward et al., 1999) and, in general, of the fluvial dynamics (Ward et al., 2002), which are deeply influenced by climatic changes.

The interactions of such attributes, as well as the fluctuation between potamophase and limnophase periods, determine several effects on the community structure of benthic invertebrates (Neiff, 2001) and on floodplain ecosystems and provide a high spatial and temporal diversity (Ward et al., 1999).

Pulses of water discharge have a high degree of interannual variability in the Paraná River. The nature of these pulses is variable over a century, and even over a decade. Hydrological regularities are shown through long-term studies, which enables tendencies in hydrological variability to be determined (Neiff, 1996). Depetris et al. (2003) observed that extreme water phases do not 


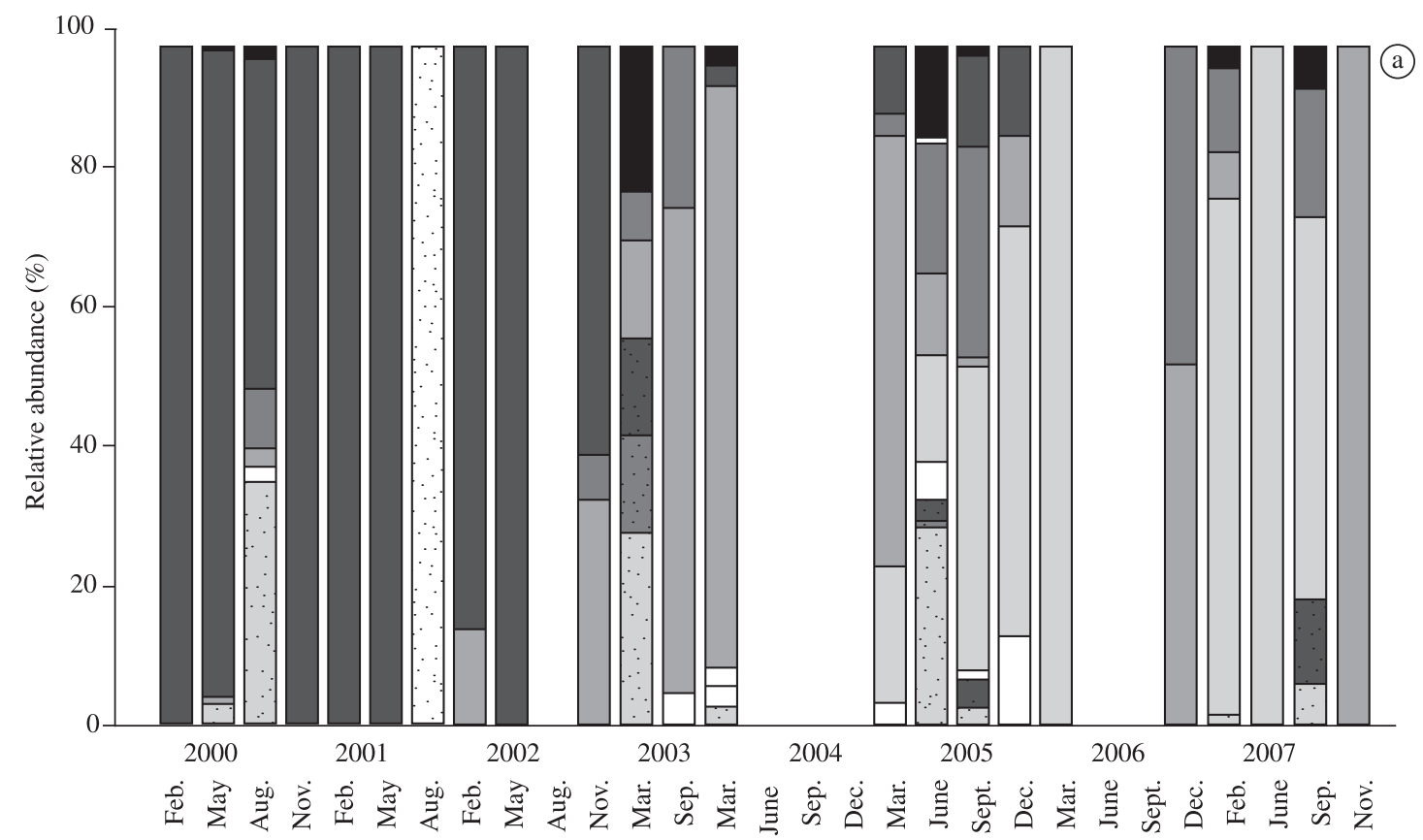

\begin{tabular}{|llll} 
Outros & $\square$ P. descolei & N. communis & $\square$ P. leidyi \\
N. bonettoi & $\square$ L. hoffmeisteri & Dero sp. & $\square$ H. aedeochaeta \\
A. pigueti & $\square$ S. trivandrana & $\square$ P. americana &
\end{tabular}

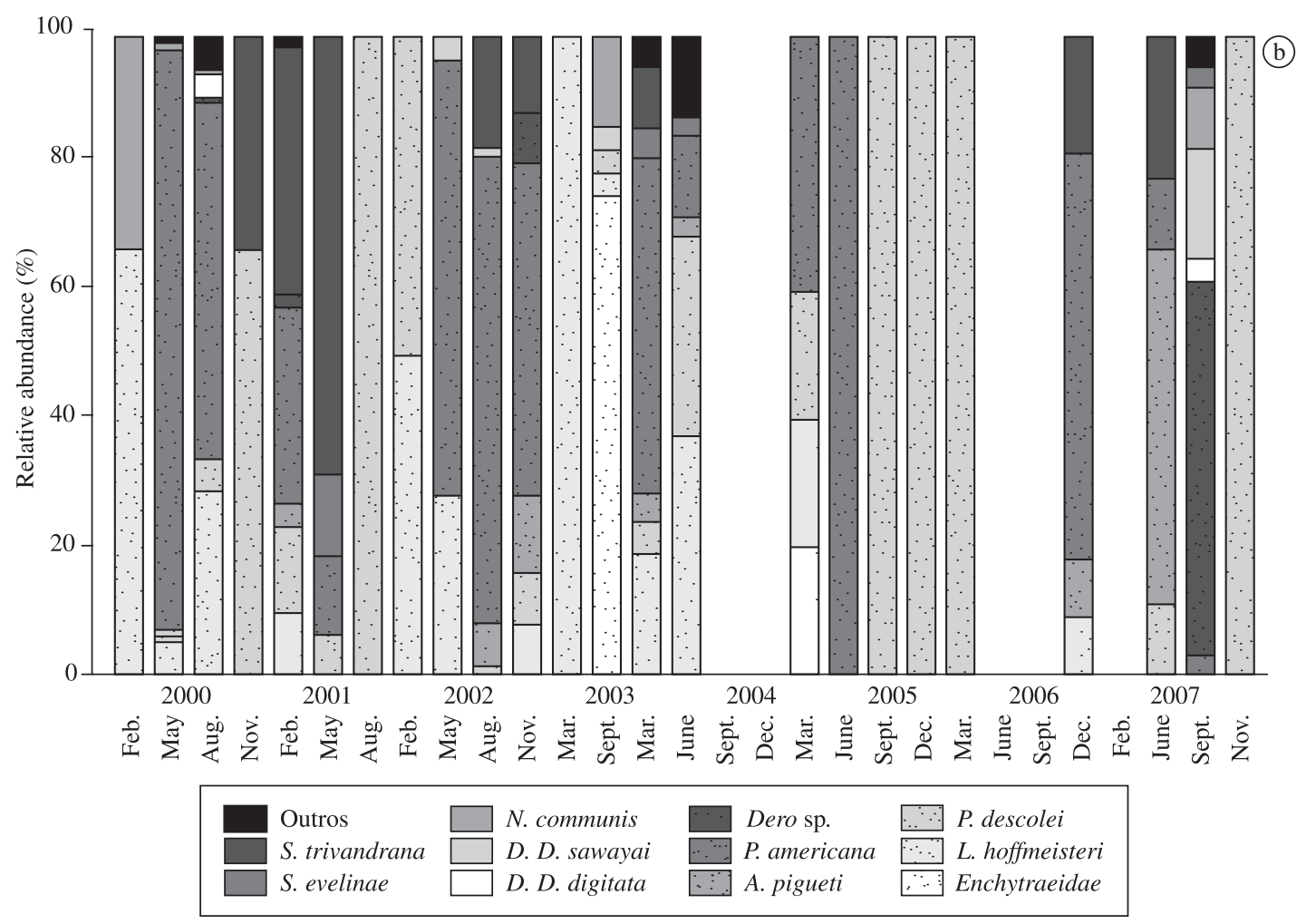

Figure 6. Relative abundance of oligochaete species in the a) Ivinhema and b) Baía Rivers. 


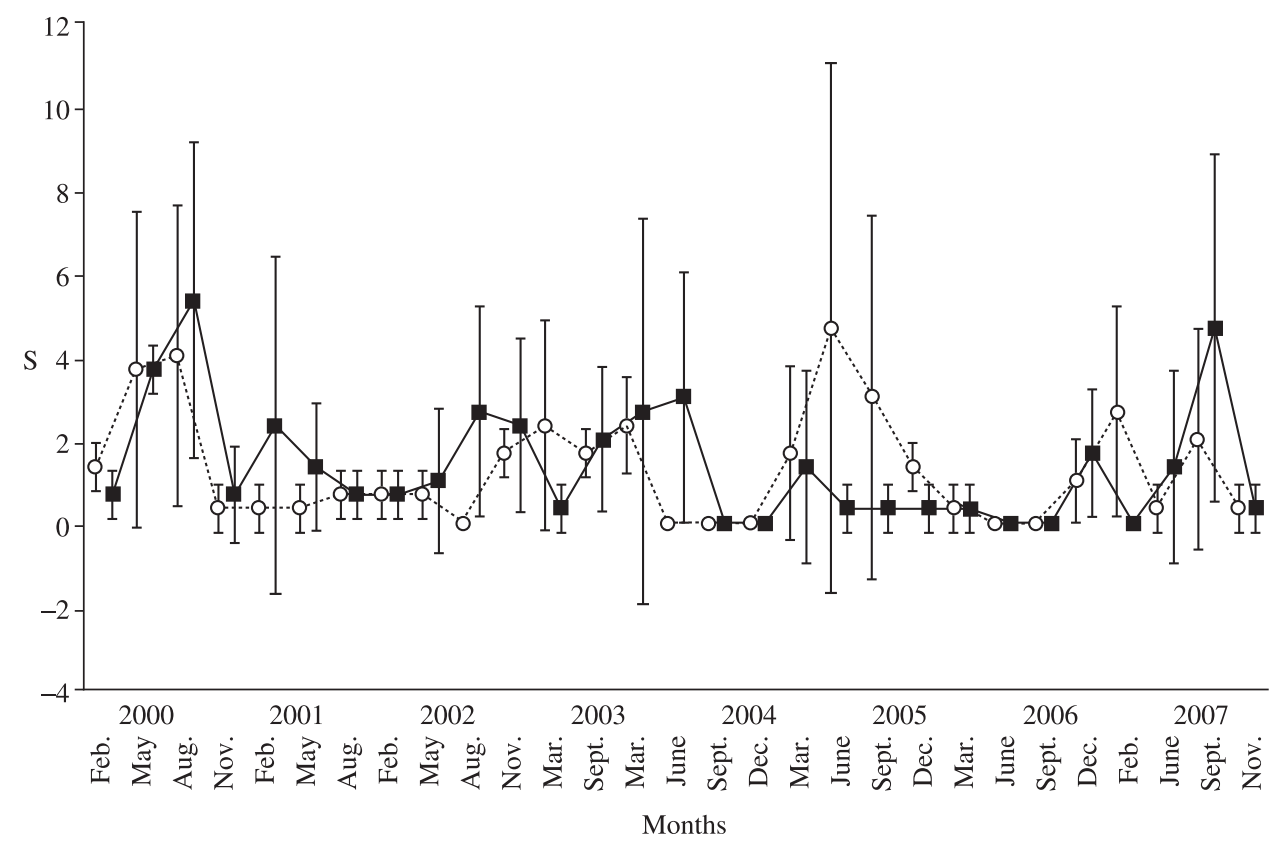

$\cdots$ Ivinhema $\rightarrow$ Baía

Figure 7. Species richness of the Ivinhema and Baía Rivers sampled over an eight year period.

always coincide with long-term hydrological records and that these phases are usually related to the global climatic phenomenon called "El Niño Southern Oscillation" (ENSO). The ENSO drives complex weather patterns such as wind direction and velocity, temperature, and the timing and amount of precipitation over cycles that return roughly every 3-7 years (Schonher and Nicholson, 1989). Future climate change may have uncertain effects on this cycle (Hoerling and Kumar, 2003).

The Paraná River recorded the lowest hydrometric levels in 2000 and 2001, possibly because of the influence of the La Niña and of the $2^{\text {nd }}$ phase formation of the Engenheiro Sérgio Motta Reservoir. Those phenomena provided the lowest values of complete pulses, intensity and amplitude of the limnophase, and the fluvial connectivity quotient, in a way that decreased the influence of this river on the other rivers studied. On the other hand, 2005 and 2007 had the highest hydrometric levels, possibly because of the presence of El Niño. That fact provided the highest values of intensity and amplitude of the potamophase and of the fluvial connectivity quotient, which increased the influence over the analyzed rivers, modifying the richness and density of Oligochaeta species.

According to the scores of the PCA axes, the rivers and the potamophase and limnophase periods could be distinguished. In the floodplain, dissolved oxygen is low during the high water phase (potamophase) when the rivers overflow because of the decomposition of some plants and the backlog of organic matter alongside the banks, and the coincidence of this period with high temperatures accelerates this process (Thomaz et al., 1997). Under such conditions, thermal stratification may last longer than 24 hours (Thomaz et al., 2004).

The oligochaeta assemblage composition of the two rivers was also separated into three groups using DCA. Group 1, which consists of several species, is formed mainly in the limnophase period. The highest values of Oligochaeta density and richness were observed in 2000 during the limnophase period and could have resulted from a decreased influence of the Paraná River water on the Ivinhema and Baía Rivers. The lower connectivity of the Paraná River with the studied environments likely increased the species richness due to high oxygen concentration. The highest richness in the Ivinhema River was observed in 2005 after a high intensity potamophase period. This high richness value could have been the result of species drifting from other places into the Ivinhema River, and potentially even from the Paraná River, which remained higher than $4.6 \mathrm{~m}$ for 33 days during 2005 . During the period of high water, the transport by drift and, consequently, the temporary colonization of habitats may increase the species richness immediately after the high water phase (Marchese et al., 2002).

In the group 2, the composition of the two rivers in the potamophase period was similar and was characterized by presence of Aulodrilus pigueti, Limnodrilus hoffmeisteri and Paranadrilus descolei. The first two species cited are found in sediments with abundant organic matter (Marchese, 1987; Montanholi-Martins and Takeda, 

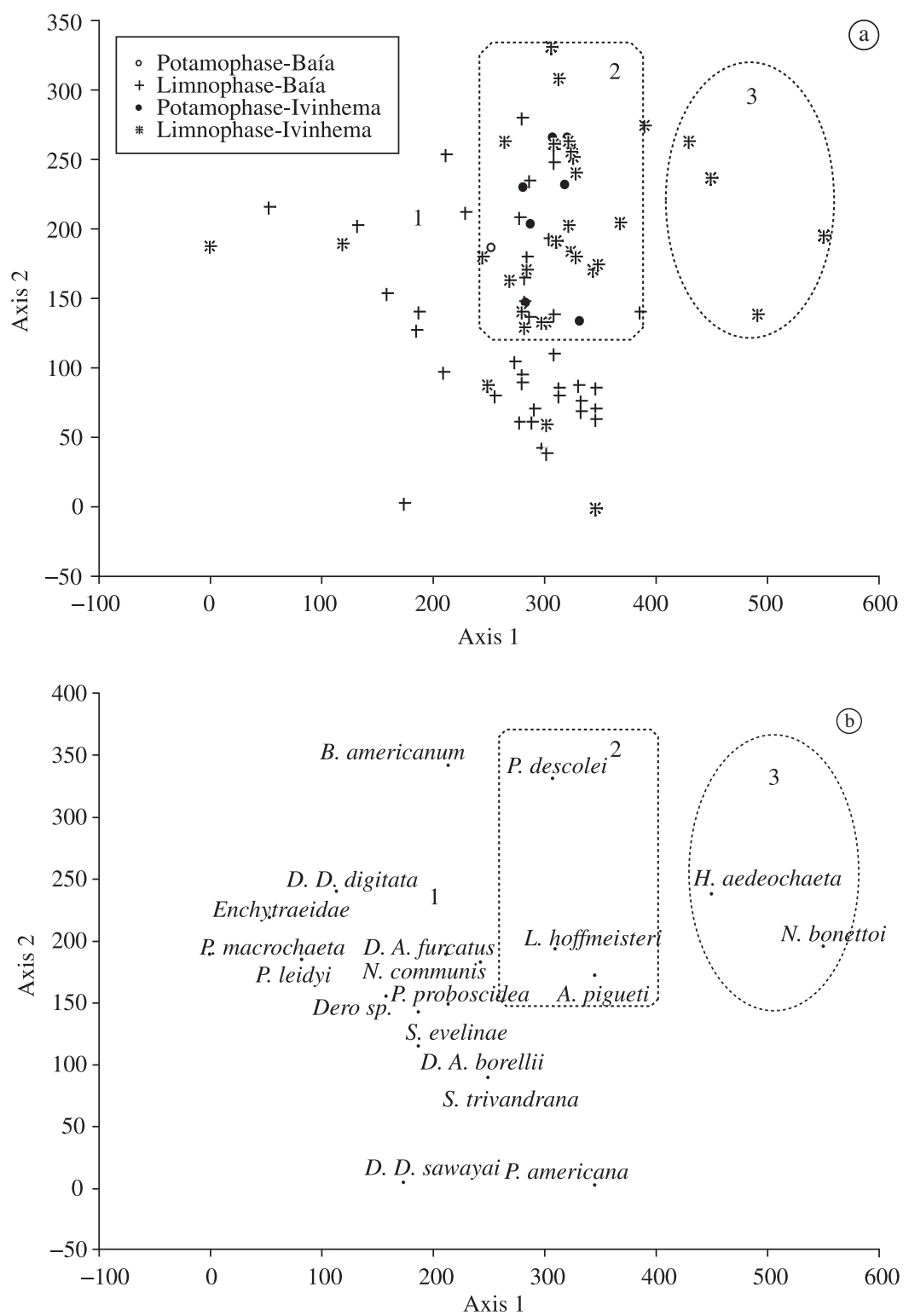

Figure 8. First two axes of the Detrended Correspondence Analysis (DCA) ordination diagram. a) Ordination of the environment/collection period scores and b) Ordination of the Oligochaete species.

1998) and possess respiratory pigments (hemocyanin), which can improve respiration in environments with low levels of dissolved oxygen (Misenderino, 1995).

Group 3 recorded high densities of $H$. aedeochaeta and N. bonettoi in the Ivinhema River from 2000 to 2002. According to Montanholi-Martins and Takeda (1998, 2001) and Takeda and Fujita (2004), the bed of the Ivinhema River is composed of pebble, gravel and sandy sediments. These two species are observed in sandy sediments of fluvial systems such as the Paraguay River (Ezcurra de Drago et al., 2004) and the Paraná River (Marchese and Ezcurra de Drago, 1992; MontanholiMartins and Takeda, 1998; 2001; Marchese et al., 2002; and Takeda and Fujita, 2004; Bletter et al., 2008). In the limnophase periods, higher densities of $H$. aedeochaeta and $N$. bonetto $i$ were observed due to the decreased influence of water currents in the sandy sediment transport these species.

In the present study, a decrease in the richness and density of Oligochaeta during the potamophase periods was observed due to the influence of the water current velocity that causes the transportation of species. However, we need more research to know how the intensity and amplitude of the potamophase influences Oligochaeta assemblage. L. hoffmeisteri, P. descolei and A. pigueti were recorded in the potamophase and in the limnophase and we concluded that they are adapted to different conditions of rivers (lotic and lentic) due to the presence 
of these species during the entire study period in both rivers. Nevertheless, these species were dominant in the potamophase periods of these rivers as they have body adaptations to survive in these conditions.

Acknowledgements - The authors are grateful for the financial support of the CNPq/PELD (Brazilian National Council for Sciences and Technology/Long Term Ecological Research) project, to the CNPq for a scholarship granted to the first author, to the Physics and Chemistry Laboratory of NUPELIA for providing water quality data, and to the Agência Nacional de Águas (ANA) and Itaipu Binacional for the hydrometric level data.

\section{References}

AGOSTINHO, AA., PELICICE, FM. and GOMES, LC., 2008. Dams and the fish fauna of the Neotropical region: impacts and management related to diversity and fisheries. Revista Brasileira de Biologia = Brazilian Journal of Biology, vol. 68. no. (4 suppl), p. 1119-1132.

BLETTER, M., AMSLER, M., EZCURRA De DRAGO, I. and MARCHESE, M., 2008. Effects of stream hydraulics and other environmental variables on density of Narapa bonettoi (Oligochaeta) in the Paraná River system. River Research and Applications, vol. 24, no. 8, p. 1124-1140.

BRINKHURST, RO. and JAMIESON, BMG., 1971. Aquatic Oligochaeta of the world. Edinburgh: Oliver and Boyd. 860p.

BRINKHURST, RO. and MARCHESE, MR., 1991. Guia para la identificacóon de oligoquetos acuáticos continentales de Sud y Centro América. Santo Tomé: Asociación de Ciencias Naturales del Litoral. 207p.

CASCO, SL., NEIFF, M. and NEIFF, JJ., 2005. Biodiversidad en ríos del litoral fluvial. Tucumán: Miscelánea. p. 419-434. Utilidad del software PULSO. Temas de la Biodiversidad del Litoral fluvial argentino II INSUGEO. Vol. 14.

CODY, ML. and SMALLWOOD, JA., 1996. Long-term studies of vertebrate communities. San Diego: Academic Press. 597p.

COLLIER, KJ., 2008. Temporal patterns in the stability, persistence and condition of stream macroinvertebrate communities: relationships with catchments land-use and regional climate. Freshwater Biology, vol. 53, no. 3, p. 603-616.

CORRADINI, FA., 2006. Processos de conectividade $e$ a vegetação ripária do alto rio Paraná - PR. Maringá: Universidade Estadual de Maringá - UEM. 70p. Dissertação de Mestrado.

DEPETRIS, PJ., PROBST, JL., PASQUINI, AI. and GAIERO, DM., 2003. The geochemical characteristics of the Paraná River suspended sediment load: an initial assessment. Hydrological Processes, vol. 17, no. 7, p. 1267-1277.

ELLIOTT, JM., 1990. The need for long-term investigations in ecology and the contribution of the freshwater biological association. Freshwater Biology, vol. 23, no. 1, p. 1-5.

EZCURRA De DRAGO, I., MARCHESE, M. and WANTZEN, KM., 2004. Benthos of a large neotropical river: spacial patterns and species assemblages in the Lower Paraguay and its floodplains. Archiv für Hydrobiologie, vol. 160, no. 3, p. 347-374.

FORTES, E., STEVAUX, JC. and VOLKMERA, S., 2005. Neotectonics and channel evolution of the Lower Ivinhema
River: a right-bank tributary of the upper Paraná River, Brazil. Geomorphology, vol. 70, no. 3-4, p. 325-338.

GAUCH Jr., HG., 1986. Multivariate analysis in community ecology. Cambridge: Cambridge University Press. 298p.

HILDREW, AG. and GILLER, PS., 1994. Patchiness, species interaction and disturbance in the stream benthos. In GILLER, PS., HILDREW, AG. and RAFFAELLI, DG. (Eds.). Aquatic ecology scale and processes. Oxford: British Ecological Society; Blackwell Science. p. 21-62.

HOERLING, M. and KUMAR, A., 2003. The perfect ocean for drought. Science, vol. 299, no. 5607, p. 691-694.

JACKSON, JK. and FÜREDER, L., 2006. Long-term studies of freshwater macroinvertebrates: a review of the frequency, duration and ecological significance. Freshwater Biology, vol. 51, no. 3, p. 591-603.

JUNK, WJ., BAYLEY, PB. and SPARKS, RE., 1989. The flood pulse concept in river floodplain systems. In DODGE, DP. (Ed.). Proceedings of the International Large River Symposium. Canadian Special Publication of Fisheries and Aquatic Sciences, vol. 106, p. 110-127.

JUNK,WJ., 1980. Áreas inundáveis: um desafio para a Limnologia. Acta Amazonica, vol. 10, p. 775-795.

LIKENS, GE., 1989. Long-term studies in Ecology: approaches and alternatives. New York: Springer-Verlag. 214p.

MARCHESE, MR., 1987. The ecology of some benthic Oligochaeta from the Paraná River, Argentina. Hydrobiologia, vol. 155 , no. 1, p. 209-214.

MARCHESE, MR., EZCURRA De DRAGO, I. and DRAGO, E., 2002. Benthic macroinvertebrates and physical habitat relationships in the Paraná River-Floodplain system. In McCLAIN, M. (Ed.). The ecohydrology of Southamerican Rivers and wetlands. Miami: International Association of Hydrological Sciences. p. 111-131. Special Publication $n^{\circ} 6$

MARCHESE, M. and EZCURRA De DRAGO, I., 1992. Benthos of the lotic enviroments in the middle Paraná River system: transverse zonation. Hydrobiologia, vol. 237, no. 1, p. 1-13.

McCUNE, B. and MEFFORD, MJ., 1999. Multivariate analysis of ecological data. Oregon: MjM Software. Version 4.0.

McINTOSH, RP., 1985. The background of ecology: concept and theory. Cambridge: Cambridge University Press. 383p.

McPHADEN, MJ., ZEBIAK, SE. and GLANTZ, MH., 2006. ENSO as an integrating concept in Earth Science. Science, vol. 314 , no. 5806 , p. $1740-1745$.

MEURER, M., 2004. Regime de cheias e cartografia de áreas inundáveis no Alto Rio Paraná, na Região De Porto Rico $P R$. Maringá: Universidade Estadual de Maringá - UEM. 54p. Dissertação de Mestrado.

MISENDERINO, ML., 1995. Composición y distribuición del macrozoobentos de um sistema lótico andino-patagónico. Ecología Austral, vol. 5, no. 2, p. 133-142.

MONTANHOLI-MARTINS, MC. and TAKEDA, AM., 1998. Communities of benthic oligochaetes in relation to sediment structure in the upper Paraná River, Brazil. Studies on Neotropical Fauna and Environment, vol. 34, p. 52-58.

2001. Spatial and temporal variations of oligochaetes of the Ivinhema River and Patos Lake in the Upper Paraná River Basin, Brazil. Hydrobiologia, vol. 463, no. 1-3, p. 197-205. 
NEIFF, JJ., 1990a. Ideas para la interpretación ecológica del Paraná. Interciencia, vol. 15, no. 6, p. 424-441.

1990b. Aspects of primary productivity in the lower Paraná and Paraguay riverine system. Acta Limnologica Brasiliensia, vol. 3, p. 77-113.

1996. Large Rivers of South America: toward the new approach. Verhandlungen Internationale Vereinigung Limnologie, vol. 26, p. 167-180.

2001. Biodiversity in some tropical wetlands systems of South America. In GOPAL, B., JUNK, WJ. and DAVIS, JA. (Ed.). Biodiversity in wetlands: assessment, function and conservation. Leiden; The Netherlands: Backhuys Publishers. p. 119-139.

, 2005. Bosques fluviales de la cuenca del Paraná. In ARTURI, MF., FRANGI, JL. and GOYA, JF. (Eds.). Ecología \& manejo de los bosques de Argentina. La Plata: Ed. Multimedia. p. 1-26.

NEIFF, JJ. and MALVÁREZ, AI., 2004. Grandes humedales fluviales. In MALVÁREZ, AI. (Ed.). Documentos del cursotaller: bases ecológicas para la clasificación e inventario de humedales en Argentina. Buenos Aires: Editora Buenos Aires. p. $77-85$.

NEIFF, JJ., IRIONDO, MH. and CARIGNAN, R., 1994. Large tropical South American wetlands: an Overview. Proceedings of the International Workshop on the Ecology and Management of Aquatic-Terrestrial Ecotones, p. 156-165.

NEIFF, JJ. and NEIFF, M., 2003. PULSO: software para análisis de fenómenos recurrentes. Buenos Aires: Dir. Nac. de Derecho de Autor 236164. Available from: <http://www.neiff. com.ar>. Access in: 10 de Setembro de 2008.

NIJBOER, RC., WETZEL, MJ. and VERDONSCHOT, FM., 2004. Diversity and distribution of Tubificidae, Naididae and Lumbriculidae (Annelida: Oligochaeta) in the Netherlands: an evaluation of twenty years of monitoring data. Hydrobiologia, vol. 520, no. 1-3, p. 127-141.

RIGHI, G., 1984. Oligochaeta. In SCHADEN, R. (Ed.). Manual de identificação de invertebrados límicos do Brasil. Brasília: Conselho Nacional de Desenvolvimento Científico e Tecnológico - CNPq. 48p.

RISSER, PG., 1991. Long-term ecological research: an international perspective. New York: John Wiley \& Sons. 294p. Scope 47.

ROCHA, PC., 2002. Dinâmica dos canais no sistema RioPlanície fluvial do Alto Rio Paraná, nas proximidades de Porto Rico - PR. Maringá: Universidade Estadual de Maringá. 169p. Tese de Doutorado.

SANTOS, ML., 2005. Unidades geomorfológicas e depósitos sedimentares associados no sistema fluvial do rio Paraná no seu curso superior. Revista Brasileira de Geomorfologia, vol. 6, no. 1 , p. 85-96.

SCHONHER, T. and NICHOLSON, SE., 1989. The relationship between California rainfall and ENSO events. Journal of Climate, vol. 2, no. 11, p. 1258-1269.

SOUZA-FILHO, EE., 2009. Evaluation of the Upper Paraná River discharge controled by reservoirs. Revista Brasileira de Biologia = Brazilian Journal of Biology, vol. 69, no. (2 suppl), p. 707-717.

STEVAUX, JC. and SANTOS, ML., 1998. Paleohydrological changes in the upper Paraná River (Brazil) during the Late Quaternary: a faciological approach. Paleohydrology and Hydrological Science, vol. 1, p. 273-285.

STEVAUX, JC. and TAKEDA, AM., 2002. Geomorphological processes related to density and variety of zoobenthic community of the upper Paraná River, Brazil. Zeitschrift Fuer Geomorphologie, vol. 129, p. 143-158.

TAKEDA, AM., 1999. Oligochaeta community of alluvial upper Paraná River, Brazil: spatial and temporal distribution (1987-1988). Hydrobiologia, vol. 412, p. 35-42.

TAKEDA, AM., SHIMIZU, GY. and HIGUTI, J., 1997. Variações espaço-temporais da comunidade zoobêntica. In VAZZOLER, AEAM., AGOSTINHO, AA. and HAHN, NS. (Eds.). Planície de inundação do Alto Rio Paraná. Maringá: EDUEM. p. 157-177.

TAKEDA, AM. and FUJITA, DS., 2004. Benthic invertebrates. In THOMAZ, SM., AGOSTINHO, AA. and HAHN, NS. (Eds.). The Upper Paraná River and its floodplain: physical aspects, ecology and conservation. Leiden; The Netherlands: Blackhuys Publishers. p. 191-208.

THOMAZ, SM., ROBERTO, MC., BINI, LM., 1997. Caracterização limnológica dos ambientes aquáticos e influência dos níveis fluviométricos. In VAZZOLER, AEAM., AGOSTINHO, AA. and HAHN, NS. (Eds.). A planície de inundação do alto rio Paraná: aspectos físicos, biológicos e socioeconômicos. Maringá: EDUEM. p. 73-102.

THOMAZ, SM., PAGIORO, TA., BINI, LM., ROBERTO, MC. and ROCHA, RRA., 2004. Limnology of the Upper Paraná floodplain habitats: patterns of spatio-temporal variations and influence of the water levels. In AGOSTINHO, AA., RODRIGUES, L., GOMES, LC., THOMAZ, SM. and MIRANDA, LE. (Eds.). Structure and functioning of the Paraná River and its floodplain: LTER - site 6. Maringá: EDUEM. p. 37-42.

WARD, JV., TOCKNER, K. and SCHIEMER, F., 1999. Biodiversity of floodplain river ecosystems: ecotones and connectivity. Regulated Rivers Research \& Management, vol. 15 , no. 1-3, p. 125-139.

WARD, JV., TOCKNER, K., ARSCOTT, B. and CLARET, C., 2002. Riverine landscape diversity. Freshwater Biology, vol. 47, no. 4 , p. 517-539.

ZAR, JH., 1984. Biostatistical analysis. New Jersey: PrenticeHall Inc. 718p. 